$\begin{array}{ll}\text { Nama } & \text { : Muhammad Muhib } \\ \text { Nim } & : 90100118010 \\ \text { Kelas } & \text { : Ekonomi Islam A }\end{array}$

\title{
MASA PEMERINTAHAN BANI UMAYYAH, BANI ABBASYIAH, DAN TURKI USTMANI
}

(Muhammad Muhib 90100118010)

\begin{abstract}
Seorang pemimpin merupakan sosok penting dalam terbentuknya suatu Negara. Konsep welfare state atau Negara kesejahteraan merupakan hubungan antara prinsip Negara tersebut dengan pemimpinnya. Karena sejatinya manusia adalah sebagai khalifah di bumi ini, yang mempunyai tugas untuk menciptakan rahmat bagi seluruh manusia di kehidupan ini dan juga untuk menciptakan baldatun thayyibatun wa rabbun ghafur, sebuah negeri yang baik. Konsep welfare state bukanlah Negara Eropa dan Amerika yang pertama kali menerapkannya, namun jauh sebelum itu Rasulullah telah berhasil menjadikan Madinah Negara yang sejatera. Setelah itu dilanjutkan oleh masa Khulafaur Rasyidin yangtercatat juga berhasil mengaplikasikan konsep welfare state. (Kusumastuti \& Ghozali, n.d.)
\end{abstract}

Di masa pra-Islam, sebagai suku Kuraisy, Bani Umayyah dan Bani Hasyim selalu bersaing untuk menduduki kursi pimpinan. Bani Umayyah lebih berperan dalam bidang pemerintahan dan perdagangan, dengan demikian mereka lebih banyak menguasai bidang perekonomian di banding Bani Hasyim, sementara Bani Hasyim adalah orang-orang yang berekonomi sederhana, akan tetapi kebanggaan Bani Hasyim adalah bahwa Rasul terakhir yang diutus Allah swt. adalah dari keturunan mereka, yakni Muhammad bin Abdillah bin 'Abd al-Muththalib.(Rachman, 2018).

Abu Abbas berkuasa hanya 4 tahun saja, dari tahun 750M-754 M dan menjadikan Hasyimiah, dekat Kufah sebagai pusat pemerintahannya. Ia memfokuskan pemerintahannya untuk menjaga stabilitas negara yang baru saja terbentuk dari ancaman serius musuh-musuhnya. Terutama dari kalangan bani Umayah, Khawarij dan syiah. Namun dibawah kepemimpinan penggantinyalah, yaitu Abu Ja'far al-Mansur yang cenderung menggunakan pendekatan tangan 
besi terhadap musuh-musuhnya, kekuasaan dinasti Abbasyiah benar-benar bisa stabil dan kokoh. Karenanya ia dianggap sebagai pendiri kedua dari Dinasti Abbasiyah. Pada masanya, ia memindahkan pusat pemerintahannya ke Baghdad. Sejak itu kota ini menjadi kota terpenting dan termaju yang membawa pesan kegemilangan peradaban Islam ke seluruh muka bumi hingga berabad-abad kemudian (Abbasiyah, 2018)

Kekalahan Ottoman dari Rusia lantas dimanfaatkan oleh kelompok Armenia untuk meminta otonomi dari kekuasaan Ottoman dengan penandatanganan Treaty of San Stefano pada 1878. Perjanjian ini menjadi salah satu sukses Rusia menumbuhkan nasionalisme pada kelompok Yunani dan Armenia di daerah mereka sendiri. Akibatnya terjadi gelombong migrasi besarbesaran dari wilayah Usmani, pada akhir 1829 tercatat sekitar dua ratus ribu Armenian tiba di Erevan dan Nakichevan dari Beyazid dan Kars(Rofii \& Zuhdi, 2020)

Kekuatan militer Turki Usmani mulai diorganisir dengan baik ketika terjadi kontak dengan Eropa dibawah kekuasaan Sultan Orkhan. Dalam bidang militer dilakukan perombakkan besarbasaran. Dilakukam pembaruan dengan memutasi personil-personil pimpinan, perombakan dalam keanggotaan dengan memasukkan non-Turki sebagai anggota bahkan anak-anak Kristen diterima menjadi tentara, mereka diasramakan dan dibimbing dalam suasana Islam. Sehingga terbentuklah kelompok militer baru yang bernama Jenissari atau Inkasyiriah. Pasukan Jenissari dapat mengubah Negara Usmani menjadi negara dengan kekuatan militer yang sangat disegani oleh lawan-lawan politik Sultan.(Nofrianti \& Muslim, 2019) 


\section{DAFTAR PUSTAKA}

Abbasiyah, D. (2018). PERKEMBANGAN EKONOMI ISLAM PADA MASA DAULAH ABBASIYAH. ISLAMIC BANKING, 4(1), 45-56.

Kusumastuti, A. S., \& Ghozali, M. (n.d.). Konsep Welfare State Pada Kebijakan Umar Bin Abdil Aziz Sebagai Khalifah Bani Umayyah. Laa Maisyir. 6(2), 282-296

Nofrianti, M., \& Muslim, K. L. (2019). Kemajuan Islam Pada Masa Kekaisaran Turki Usmani. FUADUNA: Jurnal Kajian Keagamaan Dan Kemasyarakatan, 03(01), 22-32.

Rachman, T. (2018). Bani Umayyah Dilihat dari Tiga Fase ( Fase Terbentuk, Kejayaan dan Kemunduran ). 2(1), 86-98.

Rofii, M. S., \& Zuhdi, M. L. (2020). Pengaruh Kejatuhan Khilafah Turki Utsmani terhadap Perubahan Paradigma Pembangunan Negara-Bangsa Indonesia. Jurnal Middle East and Islamic Studies, 7(1), 403-405. 